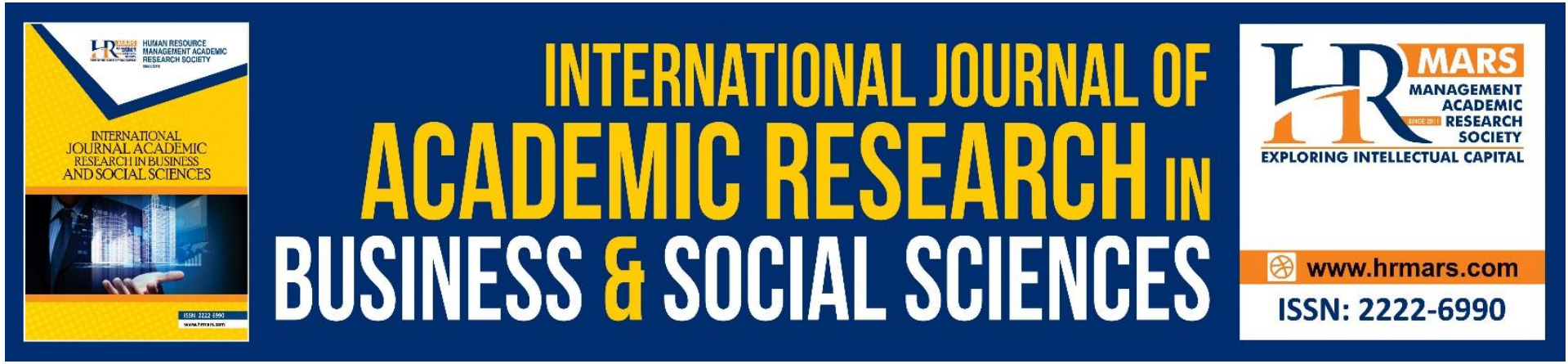

\title{
Challenges on Malaysian Teachers's Self Efficacy in Online Teaching During COVID-19
}

Khadijah Khalilah Abdul Rashid, Sueraya Che Haron, Sabrina Che Haron

To Link this Article: http://dx.doi.org/10.6007/IJARBSS/v11-i9/10806

DOI:10.6007/IJARBSS/v11-i9/10806

Received: 01 July 2021, Revised: 24 July 2021, Accepted: 26 August 2021

Published Online: 13 September 2021

In-Text Citation: (Rashid et al., 2021)

To Cite this Article: Rashid, K. K. A., Haron, S. C., \& Haron, S. C. (2021). Challenges on Malaysian Teachers's Self Efficacy in Online Teaching During COVID-19. International Journal of Academic Research in Business and Social Sciences, 11(9), 649-658.

Copyright: (c) 2021 The Author(s)

Published by Human Resource Management Academic Research Society (www.hrmars.com)

This article is published under the Creative Commons Attribution (CC BY 4.0) license. Anyone may reproduce, distribute, translate and create derivative works of this article (for both commercial and non-commercial purposes), subject to full attribution to the original publication and authors. The full terms of this license may be seen at: http://creativecommons.org/licences/by/4.0/legalcode

Vol. 11, No. 9, 2021, Pg. 649 - 658

http://hrmars.com/index.php/pages/detail/IJARBSS

JOURNAL HOMEPAGE

Full Terms \& Conditions of access and use can be found at

http://hrmars.com/index.php/pages/detail/publication-ethics 


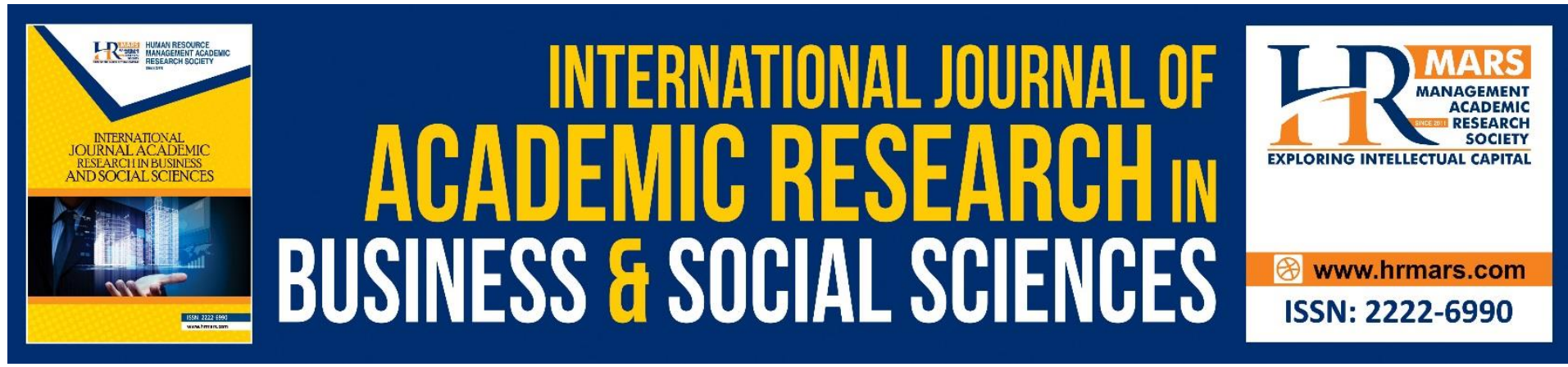

\title{
Challenges on Malaysian Teachers's Self Efficacy in Online Teaching During COVID-19
}

\author{
Khadijah Khalilah Abdul Rashid \\ Kulliyyah of Education, International Islamic University Malaysia \\ Email: khadijahkhalilah@iium.edu.my \\ Sueraya Che Haron \\ Kulliyyah of Education, International Islamic University Malaysia \\ Email: sueraya@iium.edu.my \\ Sabrina Che Haron \\ CITRA Centre, National University Malaysia \\ Email: sabrinaharon@ukm.edu.my
}

\begin{abstract}
Realizing online lessons during COVID-19 needs huge participation from both teachers and students. It is not easy to maintain teachers' performance in this unusual time. There are many challenges faced by teachers in online teaching during this pandemic. This study reviews literature to find out Malaysian teachers' self-efficacy related to their performance in online teaching based on Bandura's four main sources of self-efficacy. This study has its importance in revealing true challenges experienced by the teachers to deliver online lesson especially in Malaysia. This is a descriptive study that is enriched with literature on Malaysian teachers' challenges in online teaching from different published resources from the past two years such as journal articles, newspapers and online essays. The results show that the challenges related to self-efficacy faced by Malaysian teachers are their unreadiness in conducting online teaching, low motivation caused by various problems, pressure in balancing teaching duty and household chores, and worrying about the adoption and acceptance of students for online learning. These challenges were categorized based on sources of self-efficacy, that consists of mastery teaching experience, vicarious experience, social persuasion and physiological and emotional behaviours. It is concluded that the most effective way to obtain high self-efficacy level is through mastery experiences. This study proposes further research on solutions for the challenges related to teachers' self-efficacy by implementing Bandura's four main sources of efficacy beliefs.
\end{abstract}

Keywords: Self-Efficacy, Sources Of Self-Efficacy, Online Teaching, Covid-19, Malaysian Teachers 


\section{Introduction}

There are many sectors that are affected after the spread of COVID-19 around the world since the end of 2019 including education. Online teaching has been conducted among teachers in the most educational institutions during the pandemic of COVID-19 in order to fulfil learning needs for students (Moorhouse, 2020). Almost all institutions have adopted a new norm, different from what it used to be. The teaching process was transformed from face-to-face to an online teaching environment that heavily relied on technology. There are many challenges faced by the teachers to keep the learning and teaching well. Sueraya, Khadijah, Sabrina, Arifin and Nurazzelena (2021) categorize these challenges into extrinsic and intrinsic where the latter category involves the teacher, such as having no appropriate knowledge and skills to use online tools, having limited time in planning online lesson and conducting online assessment and having difficulties in managing time between workloads and household chores. One of the ways to maintain the online lesson is developing teachers' self-efficacy.

\section{Teacher Self-Efficacy}

The main idea of self-efficacy was initiated by Bandura in his social cognitive theory in the 1960 's. The core constructs of this theory are self-efficacy and outcome expectancies such as physical, social and self-evaluative (Luszczynska \& Schwarzer, 2005). Bandura (1977) defines self-efficacy as a person's particular set of beliefs that determine how well one can execute a plan of action in prospective situations. It is not related to the ability of doing something, but referring to someone's belief in the abilities and skills to achieve the goals. This belief can help teachers build their efficiency in teaching during this unusual time and overcome every challenge faced by them.

Self-efficacy can also be understood by its levels which are high self-efficacy and low selfefficacy. The first one leads someone to apply something when they feel like they have the ability and probability to achieve the goal. While the second occurs when someone has no feeling of ability to do something to achieve the goal (Zimmerman \& Cleary, 2006). For example, a social science researcher may have a high self-efficacy for doing the library research about some issues, but low self-efficacy for clinical research which is dealing with laboratory equipment.

The teachers' performance has a great impact on the students during the online learning process. If the teachers have excellent performance, they will impact students' achievement. The concept of teachers' efficacy plays an important role in explaining differences in overall teacher effectiveness with high levels of efficacy having positive effects on several student and teacher outcomes. However, little attention has been devoted to teacher efficacy in ethnically diverse classrooms (Geerlings et al., 2018).

To get through a new norm in teaching during this pandemic, the teachers must have high level of efficacy in using technology tools to conduct the online teaching. It means that the teachers should have the belief they can utilize the ICT tools to make the online lesson amazing and successful. The study of Sema, Sakip and Zeynal (2011) investigates the level of primary school teachers' self-efficacy towards instructional technologies. The result of this study concluded that they have high self-efficacy towards instructional technologies as they have an understanding of how technology can be integrated into the lesson. In order to get the high satisfaction of teachers' self-efficacy in conducting online teaching, they must have 
high belief when using the technology, as the result, Aysun and Seda (2010) revealed that there is a significant positive relationship between teachers' self-efficacy and their Internet self-efficacy. It can be indicated that generally high levels of using technology self-efficacy are related to high levels of teachers' self-efficacy in online teaching. It can be explained from the literature above that a teacher's self-efficacy plays an important part in determining the success of online teaching.

\section{Main Sources of Self-Efficacy}

One necessary attribution to realize the online teaching among teachers is self-efficacy compared to physiological and emotional conditions (Hampton et al., 2020), (Shahzad \& Naureen, 2017). However, there is no standard to measure self-efficacy because it is taskspecific (Heslin \& Klehe, 2006). Bandura (1977) stated individuals develop their self-efficacy by interpreting information from four main sources of efficacy beliefs that are mastery teaching experience, vicarious experience, social persuasion and physiological and emotional behaviours.

Bandura (1977) agreed that the most effective way of creating a successful sense of efficacy is through mastery teaching experience. If people experience only easy successes they come to expect quick results and are easily discouraged by failure. The effects of failure on selfefficacy depend on the timing and the total pattern of experiences in which the failures occur (Loo \& Choi, 2013). A resilient sense of efficacy requires experience in overcoming obstacles through perseverance. For teaching purposes, Shahzad and Naureen (2017) suggested the teachers do activity by sharing their own success stories to gain confidence in their methods. As a result, it leads them to having a strong faith in their abilities and will raise the level of teachers' self-efficacy.

Vicarious experience is the second way of creating success self-efficacy. It can be applied through the excellent performance provided by social models that have similarities to oneself. By witnessing the models' success stories, someone will perform the highest ability of himself to achieve the target. Seeing people similar to oneself succeed by sustained effort raises observers' beliefs that they too possess the capabilities to master comparable activities to succeed (Bandura, 1977). In teaching, the teachers seek proficient models who they aspire especially in teaching. They can be influenced through the models' behaviour, ways of thinking and success experiences to generate positive thoughts and enhance effectiveness of themselves (Shahzad \& Naureen, 2017).

The third source of self-efficacy is social persuasion. Usher and Pajares (2006) defined it as feedback, judgements and appraisals from significant people about engaging in related tasks. It can be understood that individual self-efficacy can be changed through valuable suggestions from significant people. Bandura (1977) explained this by explaining two different persuasions. People who are persuaded that they have the abilities to master the tasks given are likely to perform greater effort and try solving any problems that arise. However, people who are persuaded that they have lack abilities to complete their tasks tend to focus on what they lack and give up quickly when faced with difficulties. For teachers' self-efficacy, social persuasion occurs when they see a clear improvement in their attitude from appreciation and encouragement remarks (Shahzad \& Naureen, 2017). 
Finally, physiological and emotional behaviours refer to arousal, anxiety, stress, and fatigue, and this is the fourth source of information (Usher \& Pajares, 2006). Knowing their abilities, people also rely on their physiological and emotional behaviours. They interpret their stress reactions, tension, aches and pains as signs to poor performance (Bandura, 1977). While a positive mood, happiness and health enhances one's perceived self-efficacy. The teachers' confidence has the ability to make a huge change in their actions and results towards teaching and students, and it can be done by increasing their physical and emotional well-being and reducing negative emotions (Usher \& Pajares, 2006). Although (Hampton et. al., 2020) and (Shahzad \& Naureen, 2017) differentiate between self-efficacy and physiological and emotional conditions, they cannot be separated as both are influenced by each other.

\section{Challenges on Self-Efficacy Faced by Malaysian Teachers' in Online Teaching}

Maintaining a good self-efficacy of the teachers during this pandemic COVID-19 is not an easy task. The process of online teaching and learning has yet to reach the level of satisfaction for teachers and students (Sueraya et. al., 2021). This satisfaction deals with teachers' belief in their abilities performing in online lessons and facing problems that arise.

Before the pandemic, the online learning system already existed in most instituition especially in tertiary education. Embi, Hamat and Sulaiman (2012) conducted a survey to discover the use and effectiveness of online learning systems in tertiary education in Malaysia. The finding shows that only $77 \%$ of lecturers use the system, but it is low considering most universities in Malaysia have this system in operation. The most common reason given by the respondents who are the lecturers for not using the system is the lack of training or skill, so they prefer face-to-face methods. However, the teachers have no option to choose in this unusual time and must realize the lesson by doing online teaching even if they are not ready to do it ("Cabaran mengajar", 2020). "Pdpr beri peluang" (2021) reported that only after a week since the school session started in Malaysia, there is dissatisfaction among parents with the implementation of teaching and learning at home (PdPR). They claim that the teachers are not ready to teach. However, teachers should not be blamed. As the online teaching training was not properly taught before the implementation, challenges arose along the way when the teachers were exploring the use of online educational technologies in delivering the lessons because of limited technological knowledge to utilise online educational technologies properly (Wen \& Kim, 2020).

The teachers' motivation relates to their self-efficacy towards online teaching. The efficacy of both teachers and students will lead to a successful online lesson. Students who are new to the online environment or who have lower motivation may fall behind or get confused (Tiwari, 2020). The respondents among Ghanaian students in Adarkwah (2020) study believed the motivation of both teachers and students would improve the effectiveness of online learning. Börü (2018) categorizes motivation resources into two types; internal and external as he determined based his finding that the internal motivation resources come from immaterial aims, success and personal characteristics.

Facing challenges in conducting online teaching, the teachers need a strong motivation to make the lesson more effective. The problems are not limited to the line connectivity, but they extend to the emotion and psychology of the teachers. They are thinking about some matters for example acceptance from the students during the online teaching process, the 
students having no devices to get online, and the rumor on teachers getting paid without attending school (Azlin, 2020). Malaysian teachers are facing these challenges too. After more than a year experiencing online lessons, the students seem to be getting bored and no longer motivated to attend the lesson with teachers and the attendance is declining ("Kehadiran merosot", 2021). Other than working harder to adapt with new norms in teaching, teachers have to be more creative to conduct online teaching ("Guru perlu lebih", 2021). But, they still face problems with students' complaints about the absence of devices. Hawati and Jarud (2020) reported that $37 \%$ of Malaysian students have no appropriate devices to support their online lesson. It can lead to low motivation among teachers in thinking of their students' problems. Besides, the motivation of Malaysian teachers is also influenced by society accusing them of getting paid for doing nothing with the implementation of online teaching during Covid-19 pandemic ("Stop accusing teachers", 2021). The fact is, the teachers have to perform their responsibility by preparing and conducting online teaching from home.

The order from the Malaysian government to stay at home makes all family members doing all their duties in the same place; house. All educational institutions and offices were closed. Parents are working and attending online meeting from home, while children are joining online lesson at home too. Moreover, working from home during this pandemic entails its own problems for parents as well as teachers, since many teachers are also parents themselves. "Teachers students parents" (2021) reported a teacher at Sabah has to conduct online teaching for her students and at the same time has to help out with her children's online lessons. Many are caught in challenging situations that require striking a balance between work, household chores and care work, as well as enabling and supervising their confined children's learning at home (Hawati \& Jarud, 2020). Teachers that work from home can be distracted by their housework and childcare (Zhang et al., 2020). Deswari (2020) agrees the teachers need a stable mental and physical stamina to manage the household chores like cooking, cleaning, washing, preparing for children's online lesson and buying groceries more effectively than usual because everyone is doing their duties at home from morning till night, because the teachers and at the same time are parents were stressed to balance their work as teachers and duties at home (Rawal, 2021; Deswari, 2020).

Teachers cannot avoid worrying students' adaption in online learning. They have to make sure the students attend the lesson, but the teachers cannot check students' presence in front of the computer, laptop or phone if the cameras are turned off. The teachers also try to get students' attention by calling their names, sometimes without any response ("Virtual education", 2020). The poor Internet connectivity and the absence of smart devices from the students will lead to teachers' worries too. Not all the students live in places that can get good Internet signals, especially those staying in the rural areas ("Cabaran pengajaran", 2020; "Virtual education", 2020). The students need to use technological devices and subscribe to the Internet to get online for the lesson. The teachers have to deal with the students that come from the family with financial problems, and having no enough budget to own the devices and purchase the Internet passes ("Cabaran mengajar", 2020; "Cabaran pengajaran", 2020). In addition, they have to know students' socio-economic status (Bahrom, 2020). The teachers' worries came into reality when a secondary student in Perak, Malaysia was seriously injured after being involved in an accident ("Pelajar kemalangan", 2021). She tried to go to her uncle's house to get good Internet access as she wanted to attend the online class. While a teacher in Keningau (one of interior divisions in Sabah, Malaysia) admits that they are very 
worried about his students learning during this pandemic because they do not have Internet access and have been left far behind ("Pdpr: Internet lembab", 2021).

\section{Discussion}

The findings of this study can be concluded that the teachers' self-efficacy in online teaching during this pandemic related to their unreadiness in conducting online teaching because lack of skills and training, low motivation caused by various problems, stressing to balance teaching duty and household chores, and worrying about the adoption and acceptance of students in online learning. These challenges related to self-efficacy experienced by teachers in online teaching during COVID-19. The findings are highlighted based on Bandura's four main sources of efficacy beliefs that are mastery teaching experience, vicarious experience, social persuasion and physiological and emotional behaviours.

The first source is presented to the challenge of the teacher for not being ready in conducting online lessons. The biggest cause is lack of skills and training. They do not have time to be trained as the virus caused by COVID-19 was spreading rapidly. By recognizing this challenge, the teachers may overcome it by mastering teaching experience. Joining seminars and workshops in conducting online lesson platforms will help them acquire teaching in a new norm. Malaysian Muslim Teachers' Association (i-Guru) president Mohd Azizee Hasan declared that teachers have to equip themselves with adequate digital skills and to master elearning geared towards knowledge dissemination ("Virtual education", 2020). This virus affects the whole world, so that the teachers should grab the opportunities by getting the information in managing online lessons from the educators and education sectors around the world.

Bandura's next source of efficacy beliefs suggested learning from others' success experience. The teachers are facing challenges in balancing teaching duty and household chores because they are working at home. Multitasking (Eseryel et al., 2021) and good time management (Abdel-Hussein, 2020) are the key to success. The teachers can manage their time wisely and do both duties to generate high self-efficacy in conducting the online lesson. Online lessons are not a responsibility for teachers only, but the institutions' management need to adopt new strategies in teaching, pedagogy, assessment and skills to utilize ICT tools to be successful and confident (Hampton et. al., 2020).

The source of efficacy beliefs of social persuasion is related to appreciation and remarks from the students to the teachers. They are concerned about their students' acceptance in online learning. So, they can get appreciation when the students have a clear improvement and understanding from the topics taught to them. The feedback can be highly informative as it points towards gaps between one's current understanding and what is aimed to be understood (Hattie \& Timperley, 2007). The teachers also can be rewarded as a token of appreciation to motivate them doing better in conducting online lesson during this pandemic (Terenko \& Ogienko, 2020)

The last source is physiological and emotional behaviours. This source has a strong relationship with teachers' self-efficacy to get a big result as a learning outcome among their students. Besides being in a good condition while teaching, the teachers need to give some good words to encourage the students to join the online lesson and participate in all activities 
given. Having a stable emotion to conduct lesson in unusual time, they have to make more preparation with technology tools as teaching materials before starting online session compared to face-to-face session that they only focus preparing the teaching methods in classroom (Ajmain et al., 2020). Hashim (2020) suggested some advice to avoid physiology and psychological pressure during this pandemic which are staying healthy, following the government's COVID-19 orders and the most important is do not believe in any fake news related to COVID-19. A stable emotion of the teachers will make an impactful action during teaching, while the teachers with low motivation will cause students' performance in online lessons.

\section{Conclusion}

From the discussion above, it can be concluded that teachers' efficacy can be developed by four main sources. Bandura (1998) agreed that the most effective way to have a high selfefficacy level is through mastery experiences rather than three efficacy sources. The selfefficacy challenge that the teachers' have in online teaching during COVID-19 pandemic can be faced by mastering a variety of techniques and methods in conducting online lessons to get more experiences on it. But, it cannot be declared that the three sources are not important to increase teachers' efficacy as they have to make online lessons more interesting and acceptable among students.

\section{Reference}

Abdel-Hussein, W. W. (2020). The impact of time management on the success of service organizations. Technium Soc. Sci. J., 5, 249.

Ajmain, M. T. J., Sharul, F. A. M., Hehsan, A., Haron, Z., Abu-Husin, M. F., \& Junaidi, J. (2020). Covid19: the benefits of informatiom technology (it) functions in industrial revolution 4.0 in the teaching and facilitation process. Journal of Critical Reviews, 7(7), 812817. doi:10.31838/jcr.07.07.149

Bahrom, Z. (2020). Pedagogi norma baharu: cabaran dan hikmah. Jurnal Refleksi Kepemimpinan, 3. http://myjms.mohe.gov.my/index.php/jrk/article/view/9896

Bandura, A. (1977). Self-efficacy: toward a unifying theory of behavioral change. Psychological Review, 84, 191-215. https://doi.org/10.1037/0033-295x.84.2.191.

Börü, N. (2018). The factors affecting teacher-motivation. International Journal of Instruction, 11(4), 761-776. 10.12973/iji.2018.11448a.

Cabaran mengajar dalam talian. (2020). Sinar Harian..https://www.sinarharian.com.my/article/76874/BERITA/Nasional/Cabaranm engajar-dalam-talian

Cabaran pengajaran secara dalam talian. (2020). Media Permata. https://mediapermata.com.bn/cabaran-pengajaran-secara-dalam-talian/

Deswari, S. (2020). Overcoming the challenges of online teaching. British Council. https://www.teachingenglish.org.uk/blogs/sakilandeswari/overcoming-challengesonline-teaching

Embi, M. A., Hamat, A., \& Sulaiman, A. H. (2012). The use of learning management systems among Malaysian university lecturers. International Journal of Learning, 18(4).

Eseryel, U., Jiang, D., \& Eseryel, D. (2021). New findings on student multitasking with mobile devices and student success. Journal of Information Technology Education: Innovations in Practice, 20(1), 21-35. https://www.learntechlib.org/p/219441/. 
Ghavifekr, S., Kunjappan, T., Ramasamy, L., \& Anthony, A. (2016). Teaching and learning with ICT tools: issues and challenges from teachers' perceptions. Malaysian Online Journal of Educational Technology, 4(2), 38-57.

Guru perlu lebih kreatif mengajar ketika pandemik. (2021). Berita Harian. https://www.bharian.com.my/berita/nasional/2021/05/817228/guru-perlu-lebihkreatif-mengajar-ketika-pandemik

Hampton, D., Culp-Roche, A., Hensley, A., Wilson, J., Otts, J. A., Thaxton-Wiggins, A., ... \& Moser, D. K. (2020). Self-efficacy and satisfaction with teaching in online courses. Nurse Educator, 45(6), 302-306.

Hashim, N. H. (2020). Tekanan psikologikal sewaktu covid-19: emosi, usaha membendung dan konsep tawakal. https://news.uthm.edu.my/ms/2020/06/tekanan-psikologikalsewaktu-covid-19-emosi-usaha-membendung-dan-konsep-tawakal/

Hattie, J., \& Timperley, H. (2007). The power of feedback. Review of Educational Research, 77(1), 81-112.

Hawati, A. H., \& Jarud, R. K. (2020). Covid-19 and an equal learning. Khazanah Research Institute. http://www.krinstitute.org/assets/contentMS/img/template/editor/20200426_Covi d_Education_v3.pdf

Heslin, P. A., \& Klehe, U. C. (2006). Self-efficacy. In S. G. Rogelberg (Ed.), Encyclopedia of industrial/organizational psychology (pp. 705-708). Thousand Oaks.

Kehadiran merosot murid mula bosan dengan pdpr. (2021). Sabah Post. https://www.sabahpost.net/2021/06/19/kehadiran-merosot-murid-mula-bosandengan-pdpr-kata-pakar/

Luszczynska, A., \& Schwarzer, R. (2005). Social cognitive theory. Predicting Health Behaviour, 2, 127-169.

Mansor, A. N. (2020). Covid-19: cabaran buat guru. Bernama. https://www.bernama.com

Moorhouse, B. L. (2020). Adaptations to a face-to-face initial teacher education course 'forced' online due to the COVID-19 pandemic, Journal of Education for Teaching, 46(4), 609-611, DOI: 10.1080/02607476.2020.1755205

Pdpr: Beri peluang kepada guru. (2021). Harian Metro. https://www.hmetro.com.my/akademia/2021/01/668122/pdpr-beri-peluangkepada-guru

Pdpr: Internet lembab guru risau murid jauh ketinggalan. (2021, January 27). Putera Daily. https://puteradaily.com/pdpr-internet-lembab-guru-risau-murid-jauh-ketinggalan/

Pelajar kemalangan ketika cari capaian internet untuk pdpr. (2021, June 20).. Berita Harian. https://www.bharian.com.my/berita/nasional/2021/06/830168/pelajarkemalangan-ketika-cari-capaian-internet-untuk-pdpr

Rawal, D. M. (2021). Work life balance among female school teachers [k-12] delivering online curriculum in Noida (India) during COVID: Empirical study. Management in Education. https://doi.org/10.1177/0892020621994303.

Shahzad, K., Naureen, S. (2017). Impact of teacher self-efficacy on secondary school students' academic achievement, Journal of Education and Educational Development, 4(1), 4872.

Stop accusing teachers of 'makan gaji buta' during MCO. (2021). New Straits Times. https://www.nst.com.my/news/nation/2021/01/658177/stop-accusing-teachersmakan-gaji-buta-during-mco 
Sueraya, C. H., Khadijah, K. A. R., Sabrina, C. H., Arifin, M., \& Nurazzelena, A. (2021). Challenges faced by teachers in online teaching during the pandemic. Journal of Education and Practice, 12(2), 48-53. https://www.iiste.org/Journals/index.php/JEP/article/view/55298/57114.

Teachers students parents adapting to pdpr. (2021). The Sun Daily. https://www.thesundaily.my/home/teachers-students-parents-adapting-to-pdprGH8108383

Terenko, O., \& Ogienko, O. (2020). How to teach pedagogy courses online at university in covid-19 pandemic: search for answers. Romanian Journal for Multidimensional Education, 12, 173-179.

Tiwari, M. (2020). Challenges of online teaching. British Council. https://www.teachingenglish.org.uk/blogs/madhu-tiwari/challenges-online-teaching

Tunku B. T. A. (2020). Kita patut lebih kreatif, inovatif. Utusan Malaysia. https://www.utusan.com.my

Usher, E. L., \& Pajares, F. (2006). Sources of academic and selfregulatory efficacy beliefs of entering middle school students. Contemporary Educational Psychology, 31(2), 125141.

Virtual education and its challenges for teachers. (2020). The Sun Daily. https://www.thesundaily.my/local/virtual-education-and-itschallenges-for-teachersHB2416944

Wen, K. Y. K., \& Kim, H. T. (2020). ESL teachers' intention in adopting online educational technologies during covid-19 pandemic. Journal of Education and E-Learning Research, 7(4), 387-394. https://eric.ed.gov/?id=EJ1278688.

Zhang, W., Wang, Y., Yang, L., \& Wang, C. (2020). Suspending classes without stopping learning: China's education emergency management policy in the COVID-19 outbreak. Journal of Risk and Financial Management, 13(3), 1-6.

Zhang, Y., \& Ma, Z. F. (2020). Impact of the covid-19 pandemic on mental health and quality of life among local residents in liaoning province China: a cross-sectional study. International Journal Environment Research Public Health, 17(7), 1-12. 